\title{
The Role of the Nation's Identity Courses Towards Historical Value of Karawang City
}

\author{
Lusiana Rahmatiani
}

\author{
Universitas Buana Perjuangan Karawang, Indonesia \\ Corresponding author.Email: Iusiana.rahmatiani@ubpkarawang.ac.id
}

\begin{abstract}
This study aims to describe the role of the nation's identity courses in the historical value of karawang city. The fading of the identity of the nation is reflected in the young behavior of the nation such as hedonist, feudal, and individualist nature in various areas of life covering the political, social, economic, and also cultural fields and even touching the realm of ideology. The purpose of this study describes how the role of the nation's identity courses to the historical value of karawang city. The research method uses a qualitative research design with a case study approach. Data collection in this study by conducting observations, interviews, and documentation studies. The results of the study explained that the national identity course became the flagship course at Buana Perjuangan Karawang University and became a forum in reintroducing, reminding, and preserving the value of the local history of the region to students as agents of change in national and state life. The course of national identity leads students back as a young generation to be aware of the insights of the archipelago, the history of karawang city has an important role in the history of the Indonesian nation, namely the historical events of Rengasdengklok and Rawa Gede in Karawang Regency that must be maintained and preserved so that the next generation of the nation does not escape the history of the great Indonesian nation.
\end{abstract}

Keywords: Courses Identity of the Nation, History of Karawang City, Identity of the Nation.

\section{INTRODUCTION}

Today, the world of education must be able to prepare qualified and competitive human resources. The presence of globalization with a threat of ease in all areas of life, with the, marked rapid technological advances and impact on the fading of historical values in the nation's young generation. The phenomenon of fading national identity is characterized by our feudal, hedonistic, and individual behavior in various areas of life including the areas of political, social, economic, cultural, and even ideological life. The era of globalization is like a double-edged knife, on the one hand, the progress of globalization can bring a gift that is the creation of the quality of human resources in the era of progress, on the other hand, brings a very bad impact by eroding the values of national identity, one of which is the historical value of awareness of the insight of the archipelago, which until finally the country will feel a bad impact if it cannot keep up with the situation that is very potentially good or has bad potential for generation the successor of the nation. National identity is defined as the identity of the nation or the personality of the nation [1].

Education becomes an effort for a nation in preparing the younger generation to live the life of the nation and state in the future. The younger generation as holders of relay sticks will continue the struggle of the predecessors to carry out the sacred task of realizing the ideals of the Indonesian nation. The younger generation becomes a hope that will be able to do and be more devoted to the nation and the country that should be the educated young generation [2].

Research on the role of the nation's identity courses on the historical value of karawang city felt very important to be done for several reasons. First, the presence of the current globalization that influences the development of the era by marked the emergence of technological advances 
that become the main factor of the fading of the nation's history to be loved, remembered, and maintained by the next generation of the nation as the identity value of the nation by ignoring the historical value of the Indonesian nation. Second, students' ignorance about the historical insight of karawang city is one of the foundation elements in maintaining the integrity of the nation's historical values. Third, the fading of Indonesian identity values among students by no longer understanding the importance of the value of national identity in the life of the nation and state.

Through the course of national identity at the University of Buana Perjuangan Karawang became a forum in reintroducing, reminding, and preserving the historical value of the Karawang area to students as agents of change in the life of the state and nation, as well as conducting citizenship projects in the course of national identity that can be published so that the identity of Indonesia, especially the value of the Karawang history is maintained, in maintaining the identity of the Indonesian nation in order to remain me at awake.

\section{THEORETICAL REVIEW}

\subsection{Courses Identity of the Nation}

The diversity of the Indonesian nation is a source of social wealth that functions as a unifying tool for the nation and a differentiating tool from other nations [3]. Judging from the diversity of the history of the Indonesian nation, the subject of national identity needs to be applied within the University of Buana Perjuangan Karawang so that it is placed in the position of a general basic course with the course code UBP160005, which must be taught by every study program that is the hallmark of the University of Buana Perjuangan Karawang. The target of the national identity course is to equip students with an awareness of the archipelago with a basic knowledge of national identity based on the diversity of regional histories that each Indonesian nation has. This course discusses the history of Karawang as the city of origin for the struggle in particular and the history of the development of the Indonesian nation so that students can explore and understand the identity of the Indonesian nation, and students can preserve and reground the identity of the Indonesian nation in the life of society, nation and state.

The purpose of the National Identity course within the University of Buana Perjuangan, in essence, is to equip students with the basic knowledge that students hope will be able to apply Pancasila values in everyday life, by having a good personality [4]. National identity courses in the field of education are an effort to grow and instill a sense of nationalism and patriotism in students. Awareness of regional history is a provision for students to be aware of the insight of Indonesian nationality.

\subsection{History of Karawang City}

At that time, most of the Karawang area was still a swampy wilderness. This is what makes the name Karawang which comes from ka-rawa-an which means a swampy place. Until now there are still many names of areas that have swamp names such as Rawasari, Rawagede, Rawagempol, Rawamerta, and others [5]. The development of the Karawang district at this time, cannot be separated from the history of the development of the Karawang district from the Dutch colonial period to the Japanese occupation. This is closely related to several potentials possessed by Karawang Regency from several relics of the colonial period as well as Karawang's natural and human resources. This can be seen on the 1915 map of Java made by the Dutch or Kaart van Java which states that Karawang is part of the Batavia District [6].

The Rengasdengklok incident became a parameter of the nation's history that there was a sharp difference of opinion between the youth group and the old group before the Proclamation of Independence August 17, 1945, due to the failure of a youth group's request for Soekarno-Hatta to proclaim independence independent of Japan, which eventually prompted them to hold back meeting. In the meeting, it was decided that Soekarno-Hatta should be exiled out of the city to keep them away from all Japanese influence [7]. Soekarno-Hatta spent a full day in the Rengasdengklok area to pressure them to immediately proclaim independence free from ties to Japan. However, Soekarno-Hatta's authority as a senior figure in the national movement made the young kidnappers very reluctant to put pressure on them [8]. Finally reached an agreement in the negotiations that Bung Karno agreed and was willing to declare independence apart from Japanese ties. Rengasdengklok is the final stage of the journey to determine independence, which then Bung Karno-Hatta returned to Jakarta. On August 17, 1945, at 10.00 WIB (western Indonesia time), the text of the proclamation was read by Bung Karno who was accompanied by Bung Hatta at his residence at Jalan Pegangsaan Timur No. 56 Jakarta [9].

Rawagede is a village located in the province of West Java, Karawang Regency, on the western border with Tunggakjati Village, on the east with Pasir Awi Village, on the North with Sampalan Village, and the South with 
Karawang Wetan Village. In 1947 the estimated population of Rawagede village was 4,000 people, consisting of 1,300 men and 2,700 women. On December 9, 1947, there was an invasion by conducting a massive siege to Rawagede village, Rawagede village was surrounded by the Dutch who were looking for the whereabouts of Lukas Kastrio, a TNI major general who always tricked the Dutch, the Dutch were looking for Lukas Kastrio's whereabouts but none of the residents informed him of Lukas' whereabouts. Kastrio until finally the residents were shot at by the Dutch army sadistically and became a class history for the people of Karawang, especially in Rawagede village, which recorded a serious human rights case with the massacre of 431 boys and men because the Dutch did not know the figure of Lukas Kastrio so the Dutch massacred him. all Rawagede residents are male [10].

\subsection{Identity of the Nation}

Regional culture and history is a national wealth that requires serious special attention by every regional government, wherewith regional autonomy the regional government has the authority to manage the existence of regional culture and historical sites, where regional culture and history has an important role in the formation national identity in the regeneration process of the nation's successor [11]. Identity is not something genetic in a nation, identity is present through the history of the nation, and history is not a singular thing. The Indonesian nation was born from various ethnic groups with different histories, the history of the area formed a primordial identity that was different from one another [12]. The differences of each region can be framed in the verse "Bhineka Tunggal Ika" with different meanings but still one, which means that the diversity of cultures, ethnicities, customs, history, languages that exist in the Indonesian state can be integrated into a national identity that is manifested in the nation's motto as a unifying tool of the nation [13].

\section{METHOD}

The research design used in this study uses qualitative research using a case study approach. With qualitative data we can understand the chronological flow of events, can assess cause and effect in the scope of local people, and can obtain many and useful explanations. Through this approach, it is hoped that researchers can conduct a comprehensive study related to research problems [14].

\section{RESULTS AND DISCUSSION}

"Jatidiri Bangsa" Course is a public basic course that became the type of Buana Perjuangan Karawang University, with the course code UBP160005. The course of national identity discusses the national history of Indonesia to force students to be able to understand, preserve and practice the identity of the Indonesian nation in public life. The implementation of the nation's identity lectures is mastered by a special team of lecturers who get the rector's decree as a team of lecturers who are masters of the nation's identity courses. The distinctiveness of the courses of the identity of the nation became the flagship courses of the university related to the vision of the campus that is relevant to the history of the Karawang district that should not be forgotten. The course of national identity becomes one of the real efforts in fostering the love of the homeland to the students and making the initial foundation in the habituation of aware insights of the archipelago and aware of the history of the Indonesian nation that accumulates from various regional histories that form the value of identity of the Indonesian nation. The diversity of the Indonesian nation becomes a social wealth that has a function as a means of unifying the nation and becomes a differentiator from other nations [15].

The course of national identity has an important and strategic role for the needs of the younger generation of knowledge about the diversity of the Indonesian nation, the social wealth of the Indonesian nation must be nurtured well and wisely to become a tool of unifying the nation. The implementation of the study activities of the nation's identity courses is divided into two sessions, namely: The first session, lectures in the classroom with discussions about the theory of the identity of the Indonesian nation which includes the origins of the Indonesian nation, Indonesia in prehistoric times, Indonesia in the era of the Hindu kingdom, Buddhism and Islam, discussion about the era of colonialism and national struggle, as well as a special discussion about the historical events of Rengasdengklok and historical events Rawagede which has challenges in facing the existence of the identity of the nation in the era of globalization. The second session lectures outside the class (Outing class) or field practice by making a visit divided into the division of local and national visits. Local visits carry out visits to the historical places of Karawang city area namely Rengasdengklok and Rawagede as important history recorded in national history and become a milestone of the nation, thus students will have the knowledge, insight into the history of Karawang city and implement it clearly by listening to historical events from 
the resource person directly and can see the remnants of the historical heritage of the Karawang city area. Furthermore, the national visit is to visit Lubang Buaya (Pancasila Sakti Monument) and Taman Mini Indonesia Indah (TMII) this election because tmii represents all who become the embryonic state of the Republic of Indonesia, with the hope that students can add insight and knowledge about the history and insight of the archipelago following the task given by lecturers in each department.

The course of national identity has a special section to discuss the events of gross human rights violations, namely the Rawagede event that occurred on December 9, 1947, the event of gross human rights violations committed by the Dutch government against the people of Rawagede, because the Dutch army had slaughtered Rawagede people causing the death toll of 431 people. The occurrence of gross human rights violations was due to the centralism of power, absolutism of power, and military domination [16]. To commemorate the historical events built the monument as a symbol of history that depicts the heinous and sadistic events that the Dutch did to the Indonesian nation, it became very mandatory to know, especially students of Buana Perjuangan Karawang University in order to know the real history that occurred in the Karawang area which later became known as Rawagede event.

The course of the identity of the nation also has its own role in discussing the events of Rengasdengklok that we know along with the historical events of the Karawang region is a witness to national history in dissociating the independence of The Republic of Indonesia. The people of Bung Karno and Bung Hatta were taken to the house of wedana assistant Rengasdengklok Suyono Hadipranoto, who then moved the group again to the home of a Chinese named Djiau Kie Song, about 300 meters away from PETA dormitory [17].

Conceptually, the national identity course expects students to be able to have a spirit of nationalism and patriotism based on the identity of the Indonesian nation. Identity is not a genetic thing in a nation, identity is present through the history of the nation, and history is not a singular thing. Indonesians were born from different ethnic groups with different historical, historical areas forming a primordial identity that is different from each other [18].

The realization of the expected purpose in the course of the identity of this nation is students who have good character, aware of the insight of the archipelago and aware of the history of the nation equipped with basic knowledge of the Indonesian state that Pancasilais, students can practice the values of Pancasila as the value of identity of the Indonesian nation into daily life, with a good personality able to think critically, be rational, ethical, dynamic, has a broad view, able to be democratic and civilized in shaping the attitude of nationalism and patriotism instilled by the next generation of the nation. The implications of the courses of national identity towards students are expected to form students to improve the insight of the archipelago by being aware of the history of the nation as well as the history of the Karawang area. The course of the identity of the nation becomes an effort to remind the history of the region that must be maintained the authenticity of the historical story of the source who is still alive as a witness to history and even visit the historical place as a reminder of the real historical events.

\section{CONCLUSION}

The course of national identity in the Buana Perjuangan Karawang university has an important role in maintaining the regional history and realizing the vision of the campus of Buana Perjuangan Karawang University with a national reputation and national insight. The courses of national identity have an important contribution in supporting the purpose of nationhood and statehood. As a group of general basic courses, the national identity courses participate in the process of personality development that coincides with Pancasila education courses and citizenship education that have a connection with each other. The courses of national identity form students to be aware of regional history and national history as an insight fundamental Nusantara in maintaining the identity of the Indonesian nation.

\section{REFERENCES}

[1]. M. Mahfud. MD, Membangun Jatidiri Bangsa : Globalisasi Sebagai Tantangan Dan Pancasila Sebagai Imperatif Solusi, in: Sabda Jurnal Kajian Kebudayaan, 2018, pp. 145-153. DOI: https://doi.org/10.14710/sabda.13.2.145-153

[2]. Nugraha. Yogi \& Rahmatiani. Lusiana, Pelaksanaan dan Peran Kegiatan Ekstrakurikuler dalam Pembinaan Karakter Disiplin Siswa, in: Prosiding Konferensi Nasional Kewarganegaraan III Universitas Ahmad Dahlan, Yogyakarta, 2017, pp. 96-102. p-ISSN 2598-5973, e-ISSN 2599-008X 96.

[3]. Aloysius. Gunadi. Brata, Pembangunan Manusia Dan Kinerja Ekonomi Regional Di Indonesia, in: Jurnal Ekonomi Pembangunan (JEP) Kajian 
Ekonomi Negara Berkembang, 2001, pp. 113-122. ISSN: $1410-2641$

[4]. Sofyan. F. Silvia, Hubungan Mata Kuliah Jatidiri Bangsa Dengan Peningkatan Wawasan Kebangsaan Dan Semangat Nasionalisme Mahasiswa, in: CIVICS, 2017, pp 68-81. ISSN 2527-9742

[5]. Bintang. T, Sejarah Karawang Dari Masa ke Masa, Cv. Viva Tanpas, 2007

[6]. Silitonga, Y. Febrian, Firdaus. Willy, Gotama. D. Putra, Rengasdengklok Undercover, Cv. Pustakaki Press, 2018

[7]. Poesponegoro. Marwati. Djoened \& Nugroho. Notosusanto, Sejarah Nasional Indonesia VI, Depdikbud RI, 1992

[8]. Rinardi. Haryono, Proklamasi 17 Agustus 1945 : Revolusi Politik Bangsa Indonesia, in: Jurnal Sejarah Citra Lekha, 2017, pp 143-150. DOI: https://doi.org/10.14710/jscl.v2i2.16170

[9]. Bintang. T, Sejarah Karawang Dari Masa ke Masa, Cv. Viva Tanpas, 2007

[10]. Bintang. T, Sejarah Karawang Dari Masa ke Masa, Cv. Viva Tanpas, 2007

[11]. Manuaba. Putera, Budaya Daerah Dan Jatidiri Bangsa: Pemberdayaan Cerita Rakyat Dalam Memasuki Otonomi Daerah Dan Globalisasi, in: Jurnal Masyarakat, Kebudayaan dan Politik, 1999, pp. 57-66.

[12]. Zumrotus. Sa'adah, Jatidiri Bangsa Dan Potensi Sumber Daya Konstruktif Sebagai Aset Ekonomi Kreatif Di Indonesia, in: Jurnal Economia, 2015, pp 150-160. DOI: 10.21831/economia.v11i2.8239

[13]. Lisa. Retnasari \& Yayuk. Hidayah, Tinjauan Identitas Nasional Dan Identitas Kesukuan Pada Mahasiswa Pgsd Uad Yogyakarta (Studi Kasus Mahasiswa Luar Jawa Di Pgsd UAD), in: Jurnal Muslim Heritage, 2019, pp. 317-334. DOI:10.21154/muslimheritage.v4i2.1588

[14]. Miles, M \& Huberman, A. M. Analisis Data Kualitatif, UI-Press, 2007.

[15]. Brata.Aloysius. Gunadi, Pembangunan Manusia Dan Kinerja Ekonomi Regional Di Indonesia, in: Economic Journal Of Emerging Markets, 2001, pp. 113-122.

DOI: https://doi.org/10.20885/ejem.v7i2.645
[16]. F.S. Suwarno, Pelanggaran HAM Yang Berat, in: Jurnal CSIS, 2005, pp 203

[17]. Mohammad. Hatta, Sekitar Proklamasi 17 Agustus 1945, Tintamas, 1982.

[18]. Zumrotus. Sa'adah, Jatidiri Bangsa Dan Potensi Sumber Daya Konstruktif Sebagai Aset Ekonomi Kreatif Di Indonesia, in: Jurnal Economia, 2015, pp 150-160. DOI: 10.21831/economia.v11i2.8239 